\title{
Stability Value of Carbon Isotope Discrimination Tool for Durum Wheat Selection in Semi-Arid Condition
}

\author{
Hafsi Miloud*, Hadji Abbas, Semcheddine Nadjim, Rouabhi Amar and Maamri Khelifa \\ Department of Agronomy, Faculty of Life Sciences and Nature, Ferhat ABBAS University Setif, Algeria
}

Submission: September 16, 2018, Published: October 05, 2018

"Corresponding author: Hafsi Miloud, Department of Agronomy, Faculty of Life Sciences and Nature, Ferhat ABBAS University Setif, Boite Postale 718, Poste Centrale de Sétif, Sétif 19000, Algeria; Tel: +213 7 94705460; Email: hafsimiloud@yahoo.com

\begin{abstract}
Trials were conducted under contrasting rain-fed conditions in north-eastern Algeria. The stability regression coefficient was calculated for each genotype according to determine the stability of grain yield and CID across different environments. An attempt was made to classify genotypes by level of stability using grain yield and the corresponding value of $\Delta$ for each genotype. The relationship between the mean grain yield and the mean $\Delta$ across the six trials was significant. It appears that the subset of modern cultivars obtained from the CIMMYT/ICARDA durum wheat breeding program had on average, a higher $\Delta$ value (16.78\%) than the subset of local cultivars (15.82\%).
\end{abstract}

Keywords: Durum wheat; CID; Selection; Stability value

\section{Introduction}

The last study in north eastern Algeria on the potential use of carbon isotope discrimination (CID) in wheat selection conducted between 2003-2008 in collaboration with the IAEA showed several facets. Indeed, the results of seven trials in rainfed conditions characterized by a rainfall fluctuating between 250 and $500 \mathrm{~mm}$ and by additional abiotic stresses such as winter-spring cold (due to altitude) and terminal heat (because of close proximity of the Saharan desert). In this type of area, several genotypes of diverse origin were evaluated in order to measure the stability of CID values in relation to grain yield.

\section{Materiel and Methods}

Plant samples were analyzed for $\delta{ }^{13} \mathrm{C}$ to identify lines presenting a large variation for $\Delta$. Based on $\Delta$ analysis, six advanced lines from the CIMMYT/ICARDA durum wheat breeding program (Sooty9/Rascon39, Dukem12/2*Rascon, Kucuk, Mexicali, Waha) and two old Algerian cultivars (Polonicum, Oued Zenati) were selected (Table 1) evaluated from 2002 to 2007 at the Sétif experimental station. Trials were conducted under contrasting rain-fed conditions in north-eastern Algeria.

Table 1: Brief description of eight genotypes grown in season 2003-04 at Setif and Khroub stations.

\begin{tabular}{|c|c|c|}
\hline Cultivar No. & Name & Origin \\
\hline 1 & Mexicali & CIMMYT cultivar, released in 1975 \\
\hline 2 & Sooty9/Rascon57 & CIMMYT advanced line \\
\hline 3 & Waha & CIMMYT/ICARDA line (Sham 1) released in Algeria in 1986 \\
\hline 4 & Oued Zenati & CIMMYT cultivar, released in 1984 \\
\hline 5 & Altar & CIMMYT advanced line \\
\hline 6 & Dukem12/Rascon21 & CIMMYT cultivar, released in 1984 \\
\hline 7 & Kucuk & Local variety \\
\hline 8
\end{tabular}

The stability regression coefficient (b-value) was calculated for each genotype according to Finlay \& Wilkinson [1], to determine the stability of grain yield and CID across different environments. In general, genotypes with b-values: 
a. $\quad<0.70$ were considered unresponsive to different environments or had above average stability.

b. Between 0.70 and 1.30 had average stability

c. >1.30 were considered responsive to good environments or had below average stability [2].

\section{Results}

Significant differences among genotypes were observed for grain yield. The mean grain yield for all genotypes was about
1.3 times higher in 2004-05 trial than the first trial in 2006. $\Delta$ Grain for the three trials carried out from 2004 to 2006 were respectively $15.11 ; 16.45$ and $17.26 \%$. The greatest difference between extreme genotypes for $\Delta$ Grain was observed in the 2005 season $(1.39 \%)$. The smallest range for $\Delta G$ was observed in the second trial of 2006 (0.98\%o). The effect of environment, understood as the combination of region and total rainfall, on grain yield and grain- $\Delta$ was much higher than that of genotypic variability. For CID, the interaction between genotypes and trials was not significant.

Table 2: Stability parameters range and mean of grain yield and $\Delta$ from 7 trials.

\begin{tabular}{|c|c|c|c|c|c|c|}
\hline Genotypes & Grain yield (slope \pm SD) $\dagger$ & Grain yield range $\left(\mathbf{t ~ h a}^{-1}\right)$ & Mean yield (t ha-1 & $\Delta$ (slope \pm SD) $\dagger$ & $\begin{array}{c}\text { D range (\%) } \\
\text { Mean D } \\
(\%)\end{array}$ \\
\hline Altar & $0.766 \pm 0.099$ & $1.67-5.05$ & 3.15 & $1.242 \pm 0.168$ & $15.22-18.03$ & 16.55 \\
\hline Dukem & $0.915 \pm 0.203$ & $2.16-5.51$ & 3.49 & $1.090 \pm 0.124$ & $15.36-18.05$ & 17.16 \\
\hline Kucuk & $1.309 \pm 0.033$ & $2.09-7.22$ & 3.69 & $0.829 \pm 0.260$ & $15.26-17.77$ & 16.71 \\
\hline Mexicali & $1.038 \pm 0.110$ & $2.24-6.34$ & 3.55 & $0.881 \pm 0.150$ & $15.57-17.59$ & 16.69 \\
\hline Oued Zenati & $0.610 \pm 0.121$ & $1.71-4.44$ & 2.82 & $1.316 \pm 0.243$ & $14.18-17.57$ & 16.04 \\
\hline Polonicum & $0.609 \pm 0.036$ & $1.86-4.28$ & 2.73 & $1.013 \pm 0.265$ & $14.62-17.21$ & 15.8 \\
\hline Sooty & $1.317 \pm 0.204$ & $2.53-7.82$ & 3.78 & $1.206 \pm 0.260$ & $15.24-17.91$ & 16.83 \\
\hline Waha & $1.437 \pm 0.137$ & $2.06-7.87$ & 3.74 & $0.952 \pm 0.081$ & $15.44-17.40$ & 16.76 \\
\hline
\end{tabular}

†SD = standard deviation

a. An attempt was made to classify genotypes by level of stability using grain yield and the corresponding value of $\Delta$ for each genotype (Table 2) according to Finlay and Wilkinson [1]. The relationship between the mean grain yield and the mean $\Delta$ across the six trials was significant.

It appears that the subset of modern cultivars obtained from the CIMMYT/ICARDA durum wheat breeding program had on average, a higher $\Delta$ value (16.78\%) than the subset of local cultivars (15.82\%). This result is in good agreement with previous results obtained in the same type of environments. It can be explained by a lower stomatal conductance, or more likely, by less effective re-mobilization efficiency, reflected in their lower harvest index [3]. The local cultivars, and particularly Oued Zenati, yielded well under the adverse environmental conditions of the high plateau, mainly because of a better phenological adaptation. The results of the present experiments, as well as those of previous studies [4,5], suggest that $\Delta$ has a limited application as a yield predictor in this type of environment.

\section{References}

1. Finlay KW, Wilkinson GN (1963) The analysis of adaptation in a plantbreeding programme. Aust J Agric Res 14(6): 742-754.

2. Lin CS, Binns MR (1985) Procedural approach for assessing cultivarlocation data: Pairwise genotype-environment interactions of test cultivars with checks. Can J Plant Sci 65(4): 1065-1071.

3. Philippe Monneveux, Matthew P Reynolds, Richard Trethowan, Hector González-Santoyo, Roberto J Peña, et al. (2005) Relationship between grain yield and carbon isotope discrimination in bread wheat under four water regimes. European Journal of Agronomy 22 (2): 231-242.

4. Hafsi M, Monneveux P, Merah O, Djekoune A (2000) Carbon isotope discrimination and yield in durum wheat grown in the high plains of Sétif (Algeria). Contribution of different organs to grain filling. Durum Wheat Improvement in the Mediterranean Region: New Challenges, Options Méditerranéennes 40: 145-147.

5. Hasfi M, Akhter J, Monneveux P (2007) Leaf senescence and carbon isotope discrimination in durum wheat (Triticum durum Desf.) under severe drought conditions. Cereal Res Comm 35(1): 71-80. 


\section{Your next submission with Juniper Publishers} will reach you the below assets

- Quality Editorial service

- Swift Peer Review

- Reprints availability

- E-prints Service

- Manuscript Podcast for convenient understanding

- Global attainment for your research

- Manuscript accessibility in different formats

( Pdf, E-pub, Full Text, Audio)

- Unceasing customer service

Track the below URL for one-step submission https://juniperpublishers.com/online-submission.php 